Federal Reserve Bank of Minneapolis

Research Department Staff Report 248

June 1998

\title{
The Defining Moment: A Review Essay
}

Lee E. Ohanian*

Federal Reserve Bank of Minneapolis

and University of Minnesota

\begin{abstract}
This paper reviews The Defining Moment, edited by Michael D. Bordo, Claudia Goldin, and Eugene N. White. The volume studies how the Great Depression changed government policies, including changes in monetary policy, fiscal policy, banking policy, agricultural policy, social insurance, and international economic policy. I argue that a theory of policy evolution is required to answer how the Great Depression affected these policies. In the absence of this theory, the contributors provide insight into the question by showing how policies changed sharply in the 1930s with little or no historical precedent or by showing how policies were tied to political or other considerations unique to the period. While this volume doesn't always provide answers to the questions posed, it does raise a fundamental issue in the analysis of government policy: Why during some crisis periods are bad policies adopted, whereas during other periods, they are not?
\end{abstract}

${ }^{*}$ I thank Hal Cole, Narayana Kocherlakota, and Ed Prescott for helpful comments. The views expressed herein are those of the author and not necesarily those of the Federal Reserve Bank of Minneapolis or the Federal Reserve System. 
The Great Depression is infamously the grandaddy of all economic downturns in the United States. Between 1929 and 1933, the unemployment rate rose to about 25 percent, real GNP fell about 30 percent, and real gross private domestic investment fell a remarkable 85 percent. The Great Depression not only involved the largest decline in economic activity in the history of the United States, but was also characterized by an extremely slow recovery. Ten years after the Great Depression began, per-capital real output, adjusted for 2 percent trend growth, was 25 percent below its 1929 level, and the unemployment rate remained at 17 percent.

The Defining Moment, edited by Michael D. Bordo, Claudia Goldin, and Eugene N. White (Chicago: University of Chicago Press, 1998), is a collection of essays that studies how the Great Depression changed government policies. The book consists of an introductory chapter by the editors, followed by twelve chapters arranged under four sections. The first section focuses primarily on macroeconomic (business cycle) policy, with analyses of the cyclical aspects of monetary policy by Charles W. Calomiris and David C. Wheelock, the cyclical aspects of fiscal policy by J. Bradford De Long, and an essay on bank regulation by Eugene N. White. Section 2 studies how government intervention expanded during the Great Depression, with contributions by Hugh Rockoff on how economists came to favor government expansion during the period, John Joseph Wallis and Wallace E. Oates on the changing relationship between the federal government and state and local governments, and Gary D. Liebcap on changes in the regulation of agriculture. Section 3 focuses on social insurance, with studies of unemployment insurance by Katherine Baicker, Claudia Goldin, and Lawrence F. Katz, social security by Jeffrey A. Miron and David N. Weil, and an essay on changes in union membership by Richard B. Freeman. The final section considers international aspects of policy with analyses of trade policies by Douglas A. Irwin, capital flows by Maurice Obstfeld and Alan M. Taylor, and the international monetary system by Michael D. Bordo and Barry Eichengreen. 
The introductory chapter presents the organizing theme of the book: Was the Great Depression a "defining moment" for government policy? Did the government policies initiated during the Great Depression represent a fundamental break from the past, or instead, were they an acceleration of changes that had already begun to occur? These questions and the related issue of why only some of the policies introduced in the 1930s became permanent fixtures in the United States are the organizing concerns of this volume and are the questions which all subsequent chapters seek to answer.

With this goal, the authors either implicitly or explicitly conduct one of the following counterfactual experiments: How would monetary, fiscal, regulatory, and social policies, and the coordination of international trade in goods and assets have evolved over the twentieth century had the Great Depression never occurred? These are important and intriguing questions, as the answers may have implications for the development and adoption of economic policy, and the answers might tell us how the world would be different today had policy been different.

These are also very difficult questions to answer. To provide an answer using a formal theoretical framework requires knowing explicitly how households and policymakers viewed the economic performance of the 1930s. If they did not have a good understanding of the downturn, as is often presumed, then a theory of the evolution of policy in an environment in which agents are uncertain about the structure of the economy is needed to conduct the analysis. Currently, there is no generally accepted theory of policy evolution along these lines, and any such theory would likely depend in key ways on unobservable factors such as subjective beliefs about the nature of the downturn. Another reason it is difficult to answer these questions is that in addition to the Great Depression, other important shocks were occurring around the same time that could have influenced government policy, including World War I and the rise of Nazi Germany. Isolating the independent contribution of the Great Depression to the evolution of twentieth-century economic policy from 
these other episodes, without the guidance of well-established theory of policy evolution, is indeed a tall order to fill.

In the absence of such a theory, what types of arguments or evidence can be used to assess whether the Great Depression was a "defining moment"? One approach is to document changes that seem obviously linked to political or other considerations that were unique to the period or by providing a great deal of evidence that policies changed in sharp ways in the 1930s with little or no historical precedent. This approach is used in several of the chapters in this volume and, in some cases, provides considerable insight into policymaking in this period.

The studies that are most successful in this regard are also the most tightly focused, such as the study of unemployment insurance (UI) by Baicker, Goldin, and Katz. They argue that the Great Depression was not a defining moment for the introduction of UI. Some type of program would have likely emerged in the United States even without the Great Depression, as insurance programs had already been set up in other countries, and seven states in the United States had introduced bills for compulsory systems prior to 1929. Instead, they argue that the unique contribution of the Great Depression was in the design of the program. Many of Franklin Roosevelt's advisors favored a federal UI system, with uniform provisions for all states. However, the constitutionality of a federal system that distributed funds for social benefits was questioned by the attorney general, and additional concern about this arose after the Supreme Court struck down the National Industrial Recovery Act (NIRA) in mid-1935 on constitutional grounds.

The UI program that was adopted was not the national system desired by Roosevelt's advisors, but it was a federal-state system that did not raise any constitutional issues and gave states considerable flexibility with experience rating, eligibility, and benefits. Given the tension between Roosevelt and the Supreme Court, it seems plausible that concern about Supreme Court action led to a structure that minimized the chances of having the program struck down. The authors further 
suggest that had Roosevelt waited a few years, a national system could have been passed and that it probably would not have featured experience rating. This argument is more difficult to assess, but at a minimum, it seems reasonable to trace at least some features of today's UI system to the Great Depression and the conflict between Roosevelt and the Supreme Court.

The chapter by Liebcap on regulation of agriculture also makes a persuasive argument that the Great Depression was a watershed for some elements of farm policy. He does this by identifying and analyzing virtually all (over 600) agricultural laws passed since the late nineteenth century and by showing that the type of policies initiated during the 1930s not only differed considerably from earlier policies, but the policies also formed the foundation of agricultural policy through the 1960s. Prior to the Great Depression, most agricultural policy involved aid in fighting crop disease and insects, improving soil, or providing subsidized loans to farmers. During the Great Depression, this well-established pattern was broken. The main goal of the government changed from improving crop quality and yields to raising commodity prices by direct market intervention, either by controlling supplies or through government purchases of surplus commodities. In addition, this change in policy was also accompanied by a sharp and permanent increase in the number of USDA employees as well as an increase in USDA expenditures as a share of federal expenditures.

What remains unanswered is why these types of policies became acceptable in the 1930s, when similar but much more modest legislation drawn up in the 1920s had been defeated as special interest politics. Liebcap suggests that policies designed to raise farm income by keeping prices high were ultimately accepted because of the severity of the farm problem. This explanation is not entirely satisfactory, however. Although there was a decline in the farm sector in the 1930s, John W. Kendrick's (1961) data suggest that problems in the nonagricultural sector were more severe. At the depth of the Great Depression in 1932, for example, private nonfarm hours had declined about 32 percent compared to just a 3 percent decline in farm hours. If the basic reason that these policies 
emerge is because of particularly bad outcomes in specific sectors, it seems unlikely that agriculture would have been the primary beneficiary of these transfers.

Other chapters are much broader in scope and ambitious in their goals. In these cases, however, the lack of a tight theory of policy limits the extent to which sharp conclusions can be drawn regarding the legacy of the Great Depression. Perhaps the most ambitious essay in this book is by Bordo and Eichengreen, who conduct a counterfactual analysis of the development of the international monetary system. They ask a very interesting question: Would a system of fixed exchange rates have survived in the twentieth century without the Great Depression? They argue that without the Great Depression, a system of fixed exchange rates based on the pre-Great Depression gold exchange standard would have continued until World War II rather than collapsing in the 1930s, would have been suspended during the war, and would have resumed following the war.

The analysis is centered around a model of a stationary world economy on a gold exchange standard and is similar to a model of the gold standard developed by Robert J. Barro (1979). Given exogenous output, the equilibrium consists of paths of the money supply, gold production, the world price level, and the interest rate. The model is parameterized over two episodes, prewar (1928-38) and postwar (1950-71), and simulated to analyze the equilibrium under the counterfactual. Bordo and Eichengreen estimate under the counterfactual that the gold stock would have increased at a slower rate than actual and would have produced an average deflation rate of 1 percent per year, rather than the observed 3 percent inflation rate observed over the 1950-71 period.

Bordo and Eichengreen argue that it is unlikely that fixed exchange rates would have survived long after World War II. The main problem they identify is inadequate gold reserves. They suggest that rapid growth in world output and trade would have led to a situation in which the dollar balances held by the rest of the world would have exceeded the dollar value of the U.S. monetary gold stock 
(pegged at $\$ 20.67$ per ounce) and that this situation would likely have led to the breakdown of the fixed exchange rate system. They consider different policies in response to this shortage, including a pure gold standard or a pure dollar standard. They find these alternatives unlikely and argue that some type of floating exchange rate system would have emerged after war, perhaps as early as 1955. The authors therefore conclude that the Great Depression was not a defining moment for the international monetary system, and if anything, the abandonment of fixed exchange rates in the 1930s may have prolonged pseudo-fixed exchange rates (Bretton Woods system) in the postwar period.

To answer questions like "What type of world monetary system would have emerged after World War II, and how long would it have lasted?" requires a model that provides a satisfactory understanding of the welfare consequences of alternative monetary policies and exchange rate regimes in a nonstationary environment. While this type of theory does not yet exist, approaching the question in this manner raises a number of issues about the analysis. For example, Bordo and Eichengreen argue that if the Great Depression had not occurred, the pre-Great Depression system of fixed exchange rates and a gold exchange standard would have been restored following World War II. This assertion regarding the resumption of the pre-Great Depression arrangement seems reasonable if it provided higher welfare than alternative policies, such as floating rates. If this was true, however, then the authors' argument that the system would have broken down shortly after it was restored is puzzling. Under the assumption that the pre-Great Depression policy was resumed because it was good policy, it is likely that policymakers would have tried hard to maintain the system in the postwar period, or at least its welfare enhancing aspects, rather than stick to an arrangement (pegging gold at $\$ 20.67$ per ounce) that would have led to a breakdown, as the authors assume.

Of course, whether or not fixed exchange rate systems lead to better outcomes than flexible 
exchange rate systems remains an open question. Some economists have argued for reasons originally articulated by Milton Friedman (1953) that fixed exchange rates were ultimately abandoned because that system is inferior to flexible exchange rates. This view raises a question about Bordo and Eichengreen's counterfactual that the pre-Great Depression policy would have been resumed after the war. If Friedman's view is correct, then another six or seven years of experience with fixed rates in the 1930s, as assumed in the counterfactual, may actually have been enough to convince policymakers and economists by 1950 that fixed exchange rates were inferior and that an alternative exchange rate system should have been implemented after the war. These issues raise questions about the counterfactual of the postwar restoration of the 1920s international monetary system and its subsequent rapid demise.

Although it is difficult to draw definitive answers about how the Great Depression shaped the postwar international monetary order, Bordo and Eichengreen's essay succeeds in stimulating readers to think in new ways about fundamental questions in international monetary economics. Ultimately, new theory will be required to answer the question posed in this chapter, and in some of the other chapters in this book as well, but this essay provides a key starting point for the development of new theory.

While this book provides detailed and fascinating studies of many types of government policies, it surprisingly does not examine policies regarding monopoly. Dramatic changes took place in these policies in the 1930s, most of which fell under the umbrella of the NIRA. The centerpiece of the NIRA was policies that allowed much of the U.S. economy to explicitly cartelize.

For over 500 sectors, including manufacturing, banking, and wholesale and retail trade, antitrust law was effectively suspended and incumbent business leaders in each sector drew up "codes of fair competition" for each particular sector. What fair competition meant to industry leaders operating without the threat of antitrust was explicit collusion: many codes provided for minimum 
prices, output quotas, and open price systems in which all firms had to report current prices to the authority, and any price cut had to be filed in advance with the authority, who then notified other producers. Firms that attempted to cut prices were pressured by other members and were publicly berated as greedy "chiselers" by Hugh S. Johnson, the head of the NRA and one of Roosevelt's advisors. In the case of the hosiery industry, for example, selling an item below "reasonable" cost was only permitted if the actual item was discontinued or damaged and carried an officially sanctioned indelible mark of "discontinued" on the actual apparel. After much criticism, the NIRA was ultimately declared unconstitutional in May 1935.

Although this volume may not always provide definitive answers to the legacy of the Great Depression, it raises a critical question related to the evolution and adoption of economic policy: Why during some crisis periods are very destructive policies, such as the NIRA, adopted, whereas in other episodes, they are not? What factors during crises make it possible for special interests, or groups with extreme economic policy views, to gain influence? Ellis Wayne Hawley (1966) argued that after World War I, the combination of the apparent success of economic planning during the war and technological change that resulted in larger enterprises led some to believe that better outcomes were possible than those under competition. He also argued that the NIRA was largely the product of a group of economic planners led by Hugh S. Johnson, who argued that regulation of prices, wages, and production was required to move the economy out of the Great Depression. The guiding principle behind the planners' view was that competition was destructive and that price cutting led to low wages, unemployment, and low profits:

[The] NRA came as a blessed alleviation of the dog-eat-dog rule of the Anti-Trust Acts.... competition must keep its blows above the belt, and that there can be no competition at the expense of decent living [Hugh S. Johnson (1935), 178-79].

It took two years of wide-scale cartelization of the U.S. economy to begin to convince people that 
widespread monopoly was not the answer to the country's economic problems.

Hawley (1966) suggested that perhaps one reason extreme policies were adopted during the 1930s is because of an unsatisfactory understanding of their effects. This concern also seems to have played a role in Herbert Hoover's thinking during the Great Depression: "Because of lack of governmental experience... we had to pioneer a new field. As a matter of fact there was little economic knowledge to guide us" [Herbert Hoover (1952), 29]. We have learned a great deal about the quantitative effects of different government policies recently, and consequently, we are in a much better position to give advice now than in the 1930s. It seems unfathomable that some of the legislation of the 1930s could be passed today, so perhaps we no longer need to try out policies like the NIRA to understand their real costs. Nevertheless, damaging policies continue to be adopted: widespread price controls were used in the United States as recently as 1971. Understanding why bad policies are sometimes adopted, and how to prevent them, is clearly an important question, and one which this fine volume highlights. 


\section{References}

Barro, Robert J., "Money and the Price Level Under the Gold Standard," Economic Journal, 89, (March 1979), 13-33.

Friedman, Milton, "The Case for Flexible Exchange Rates," in Essays in Positive Economics, Chicago: University of Chicago Press, 1953, 157-203.

Hawley, Ellis Wayne, The New Deal and the Problem of Monopoly, Princeton, N.J.: Princeton University Press, 1966.

Hoover, Herbert, The Memoirs of Herbert Hoover, The Great Depression, 1929-1941, New York: The MacMillan Company, 1952.

Johnson, Hugh S., The Blue Eagle From Egg to Earth, Garden City, New York: Doubleday, Doran \& Company, Inc., 1935.

Kendrick, John W., Productivity Trends in the United States, Princeton, N.J.: Princeton University Press, 1961. 